УдК 322.1:332.14:338.43

http://efm.vsau.org/

\section{РЕГІОНАЛЬНЕ ПРОГРАМУВАННЯ ЯК ДІєВИЙ ІНСТРУМЕНТ СТАЛОГО РОЗВИТКУ СІЛЬСЬКИХ ТЕРИТОРІЙ ${ }^{\odot}$}

Т.В. КОЛЕСНИК, кандидат економічних наук, доцент, доцент кафедри адміністративного менеджменту та альтернативних джсерел енергіi, Вінницький національний аграрний університет (м. Вінниця)

У статті підкреслено обмежені можливості ринкового механізму щзодо регулювання екстерналій та забезпечення населення суспільними товарами. У зв'язку з иим зауважена необхідність державного регулювання економіки та пов'язаних із нею сфер (соиіальної та природокористування). Зауважено, щзо важливим інструментом такого регулювання (в контексті сталого розвитку різних територій, зокрема сільських) є регіональне програмування. Показано, щзо в Україні більшість сільських територій характеризується кризовими тенденціями, тому важливе значення має розробка $і$ реалізація регіональної програми «Сільський розвиток». Доведено необхідність поглибленого наукового аналізу програми,доопрацюювання ї̈ концептуальної схеми та конкретизації. Проведено аналіз програми в контексті концепиії $i$ Закону Украӥни «Про засади державної регіональної політики» та Державної стратегії регіонального розвитку на період до 2020 року. За ключовими напрямами програми обтрунтовано найважливімі проекти регіонального розвитку, які першочергово мають одержати державну підтримку в умовах проведення низки реформ та нової регіональної політики.

Ключові слова: державна регіональна політика, сільські території, сталий розвиток, регіональне програмування, регіональна програма «Сільський розвиток», проект регіонального розвитку.

Табл.: 1. Рис.: 2. Літ.: 14.

\title{
REGIONAL PROGRAMMING AS AN EFFECTIVE TOOL FOR SUSTAINABLE RURAL DEVELOPMENT
}

KOLESNIK Tetyana, Candidate of Economic Sciences, Associate Professor, of the Department of AdministrativeManagement and Alternatives Energy Sources, Vinnytsia National Agrarian University (Vinnytsia)

The article emphasizes the limited possibilities within a market mechanism for regulating externalities and providing citizens with public goods. Therefore, there is a

${ }^{\circ}$ KOLESNIK TETYANA, 2019 
necessity for state regulation of the economy and the related areas such as life of people and the use of natural resources. It is noted that regional programming is an important tool for such regulation (regarding sustainable development of various territories, in particular, rural ones). It is shown that most rural areas in Ukraine are characterized by crisis tendencies, therefore the development and implementation of "Rural Development» regional program is important. The author proves the need of the program in-depth scientific analysis as well as an update of its conceptual scheme and specification. The program was analyzed considering the concept and the law of Ukraine «On the principles of state regional policy» and the State Strategy for Regional Development for the period until 2020. Referring to the key directions of the program the most important projects of regional development are offered which, in the first place, should receive state support by means of a series of reforms and a new regional policy.

Key words: state regional policy, rural territories, sustainable development, regional programming, regional program "Rural Development", project of regional development.

Tabl.: 1. Fig.: 2. Ref.: 14.

\title{
РЕГИОНАЛЬНОЕ ПРОГРАММИРОВАНИЕ КАК ДЕЙСТВЕННЫЙ ИНСТРУМЕНТ УСТОЙЧИВОГО РАЗВИТИЯ СЕЛЬСКИХ ТЕРРИТОРИЙ
}

\author{
КОЛЕСНИК Татьяна Васильевна, \\ кандидат экономических наук, \\ доцент кафедры административного менеджсмента \\ и альтернативных источников энергии, \\ Винницкий национальный аграрный университет
} (2. Винница)

B статье подчеркнуто ограниченные возможности рыночного механизма регулирования экстерналий и обеспечения населения общественными товарами. $B$ связи с этим отмечена необходимость государственного регулирования экономики и связанных с ней сфер (сочиальной и природопользования). Замечено, что важным инструментом такого регулирования (в контексте устойчивого развития территорий, в том числе сельских) является региональное программирование. Показано, что в Украине большинство сельских территорий характеризуется кризисными тенденциями, поэтому важное значение имеет разработка и реализачия региональной программь «Сельское развитие». Доказана необходимость углубленного научного анализа программы, доработки ее концептуальной схемы и конкретизации. Проведен анализ программы в контексте кониепции и Закона Украинь «Об основах государственной региональной политики» и Государственной стратегии регионального развития на период до 2020 года. По ключевым направлениям программы обоснованы важнейшие проекты регионального развития, которые в первую очередь должны получить государственную поддержку в условиях реализации ряда реформ и новой региональной политики.

Ключевые слова: государственная региональная политика, сельские территории, устойчивое развитие, региональное программирования, региональная программа «Сельское развитие», проект регионального развития.

Табл.: 1. Рис.: 2. Лит.: 14.

Постановка проблеми. «Невидима рука» ринку значною мірою забезпечує розвиток економіки в режимі саморегулювання. Однак обмеженість ринкового механізму щодо забезпечення населення суспільними товарами та регулювання так 
званих екстерналій (зовнішніх ефектів), наприклад щодо забруднення довкілля,потребує участі держави в регулюванні економіки. Це переконливо довели у своїх працях А.С. Пігу, Дж.М. Кейнс, В. Ойкен, Я. Тінберген, П. Самуельсон та інші вчені. Регуляторний вплив держави має поширюватися не тільки на економіку, а й на дотичні до неї сфери - життєдіяльність людей та природокористування. Загалом він має забезпечувати збалансований розвиток усіх цих сфер на територіях, виділених за адміністративною (область/регіон, район тощо), функціональною (сільські, міські тощо) та іншими ознаками.

Важливим інструментом забезпечення збалансованого (сталого) розвитку територій, зокрема сільських, виступає регіональне програмування. Його застосування в Україні особливо важливе для розв'язання системних соціо-екологоекономічних проблем сільських територій, які займають понад $80 \%$ території країни, і де мешкає 31 \% iї населення.

Аналіз останніх досліджень і публікацій. Питання програмування сталого розвитку сільських територій України розглядали у своїх працях Л. Жерибор і Г. Судак [1], М. Ксенофонтов [2], І. Маленька [3], О. Недбалюк [4], В. Нелеп і М. Фурсенко [5] та інші вчені. Однак більшість з них не акцентує увагу на особливостях такого програмування за умов активного впровадження багатьох реформ та проведення нової регіональної політики (на засадах парадигми нового регіоналізму).

Формулювання цілей статті. Метою статті є 3'ясування науково-практичних засад програмування сталого розвитку сільських територій України в умовах проведення низки реформ та переходу до нової регіональної політики.

Виклад основного матеріалу дослідження. Як показує вітчизняний i зарубіжний досвід, дієвим інструментом сталого розвитку сільських територій $є$ регіональне програмування.

Регіональне програмування слід розглядати як важливий інструмент державної регіональної політики, яка зазвичай здійснюється на основі довгострокових стратегій, планів і програм розвитку територій або регіонів.

Регіональні програми є різновидом державних цільових програм, які можуть бути короткостроковими (терміном до 1 року), середньостроковими (від 1 до 5 років) та довгостроковими (терміном понад 5 років). Метою їх розробки і реалізації $\epsilon$ активізація економічної діяльності, підвищення якості життя населення, забезпечення економічної, соціальної та екологічної безпеки територій. Якщо регіональні програми включають усі ці цілі, то вони є комплексними, якщо ж тільки окремі, чи стосуються особливого виду територій, зокрема сільських, то спеціальними.

Класичним прикладом комплексної регіональної програми вважається федеральна програма розвитку долини р. Теннесі, реалізована на початку 1930-х рр. з ініціативи Президента США Ф. Д. Рузвельта. Її комплексний характер визначався тим, що окрім будівництва ГЕС і розвитку суміжних галузей промисловості та сільського господарства, забезпечувалося підвищення рівня життя населення та здійснювалися заходи з охорони довкілля.

Прикладом спеціальних регіональних програм можуть бути програми сталого розвитку сільських територій у СС та в Україні. У СС такі (семирічні) програми реалізуються в межах бюджетів Загальної сільськогосподарської політики. До речі, починаючи з 2007 р., їх частка у бюджетах була збільшена 310 до 25\% [6]. Метою цих програм є розвиток сільських поселень, диверсифікація сільської економіки, підтримка об’єктів інфраструктури на селі, сприяння соціальному розвитку села, 
зниження рівня бідності сільських жителів, збереження екосистем тощо.

При розробці подібних програм в Україні виникає логічне запитання: які саме території слід відносити до сільських? Ми вважаємо, що слід орієнтуватися на практику ЄС, зокрема на документи СЕМАТ (Ради Європейської конференції міністрів, відповідальних за просторовий та регіональний розвиток). У них під сільською місцевістю зазвичай розуміються малоурбанізовані території, що не мають великого за значенням міста. Відповідно, в Україні до сільських логічно відносити території, що знаходяться поза межами міст і мають переважно сільськузабудову.

Для сільських територій, власне як і для всіх інших, імперативом $є$ сталий розвиток. Орієнтація на нього отримала всеохоплюючий характер після Конференції ООН з навколишнього середовища і розвитку в Ріо-де-Жанейро 1992 року, на якій була прийнята низка важливих документів, зокрема Порядок денний на XXI століття (Agenda 21) і Принципи Ріо. Їх наскрізна ідея полягає в тому, що для забезпечення сталого розвитку територій будь якого рівня (в інтересах нинішнього та наступних поколінь) необхідно гармонізувати взаємодію трьох складових - довкілля, соціуму та економіки. На нашу думку, це можливо за умови досягнення оптимуму Парето, коли не можна підвищити ефект за однією із складових, не знижуючи ефект за іншими складовими.

Зрозуміло, що регіональне програмування сталого розвитку територій має проводитися за кожною 3 його складових і в цілому (шляхом поєднання окремих видів програмування). Це необхідно для підтримання динамічної рівноваги у територіальних соціо-еколого-економічних системах, за якої функціональні параметри елементів систем не виходитимуть за критичні межі (точки неповернення). В іншому випадку наступає або загибель їх, або деградація, наприклад, у формі банкрутства підприємств, зубожіння, депопуляції та маргіналізації населення, екологічної кризи.

При розробці регіональних програм сталого розвитку територій зазвичай застосовуються різні методи: прогнозування, програмно-цільового планування, проектного- та SWOT-аналізу тощо.

Особливості регіонального програмування сталого розвитку територій розглянемо на прикладі розробки і реалізації регіональної програми «Сільський розвиток» (далі - Програма) на основі представлення та наукового аналізу окремих блоків її концептуальної схеми (рис. 1).

Нормативно-правове забезпечення Програми складають документи методологічного та змістовного характеру, що відповідають засадничим положенням Конституції України щодо територіального устрою держави, поєднання принципів централізації та децентралізації в системі державного управління, підвищення ролі органів регіональної влади й місцевого самоврядування в забезпеченні соціальноекономічного розвитку регіонів.

Документами, що формують методологічні засади Програми, слугують Закони України «Про державне прогнозування i розроблення програм економічного i соціального розвитку України» (в редакції від 2 грудня 2012 р.) та «Про державні цільові програми» (в редакції від 12 жовтня 2018 р.).

До документів, що визначають змістовне наповнення Програми, належать: «Сдна комплексна стратегія розвитку сільського господарства та сільських територій на 2015 - 2020 роки», проект якої схвалено на Національній раді реформ 9 листопада 2015 р.; «Концепція розвитку сільських територій» (від 23 вересня 2015 р.) та план заходів з іiі реалізації (від 19 липня 2017 р.). Але оскільки ці документи регламентують ще й розвиток окремого класу територій, зокрема 


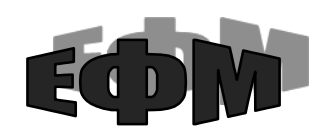

http://efm.vsau.org/ сільських, то вони мають відповідати правовим засадам державної регіональної політики, зокрема Закону України «Про засади державної регіональної політики» від 5 лютого 2015 р., теоретичним підгрунтям якої є Концепція державної регіональної політики від 25 травня 2001 p.

У Законі серед пріоритетів регіональної політики визначені й ті (в ст. 6), що є важливими для сталого розвитку сільських територій (регіонів) як проблемних, а саме: ефективного використання їх внутрішнього потенціалу, створення умов для підвищення якості життя людей та конкурентоспроможності, формування ефективної системи захисту довкілля. Важливо й те, що в ст. 7 Закону базовим документом практичної дії у сфері державної регіональної політики визначено «Державну стратегію регіонального розвитку на період до 2020 року» (далі Стратегія) від 6 серпня 2014 р.

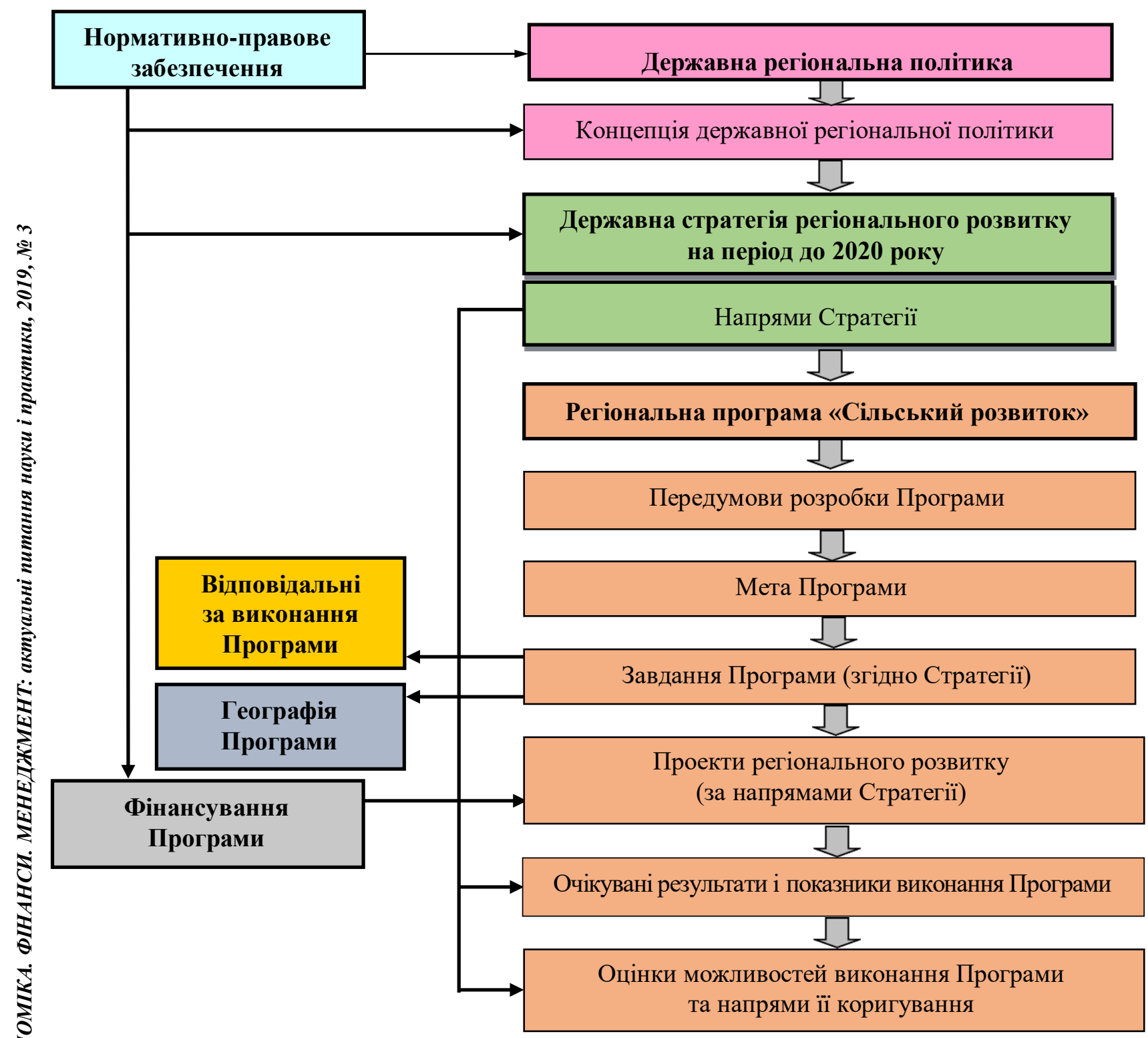

Рис. 1. Концептуальна схема розробки і реалізації регіональної програми «Сільській розвиток»

Джерело: розробка автора 
http://efm.vsau.org/

Передумови розробки Програми вказані у їі преамбулі. У ній відмічені основні «больові точки» сталого розвитку сільських територій в Україні: кількість зайнятого населення у сільському господарстві, лісовому та рибному господарстві у 2016 р. відносно 2012 р. скоротилася на 18 \%; рівень зареєстрованого безробіття у сільській місцевості на кінець квітня 2018 р. становив 1,8 \%, що в 1,8 разу перевищує такий же показник у містах; рівень оплати праці в сільському господарстві у I кварталі 2018 р. складав тільки 73,4\% від середнього рівня в галузях економіки; 73,9 \% сільських домогосподарств у 2017 р. вважали себе бідними; малою є питома вага обладнаних квартир, зокрема водопроводом - 30,6 \%, гарячим водопостачанням - 18,1\%, каналізацією - 29,9\% (станом на кінець 2016 р.); залишаються невирішеними проблеми дошкільного виховання, здобуття якісної освіти, організації дозвілля сільських жителів; громадський рух на селі та система сільськогосподарського дорадництва майже нерозвинені; рівень смертності у сільській місцевості значно перевищує цей показник у містах внаслідок бідності, відсугності кваліфікованої медичної допомоги тощо; продовжують зростати площі під звалищами відходів. Якщо до цього додати незадовільний стан більшості автомобільних доріг, відсутність швидкісного Інтернету, то стає зрозумілим, чому багато сіл є малопридатними для проживання. На це, зокрема, вказує те, що кількість сільського населення за період з 1 січня 2010 р. до 1 січня 2017 р. скоротилася майже на 10\% [8].

У зв'язку з цим виникає логічне запитання: чи є деградація сільських територій загальносвітовою тенденцією і чи слід їй активно протидіяти? Якщо звернутися до теорії технологічних укладів, то виходить, що в кожному наступному технологічному укладі роль сільського господарства має знижуватися, а отже, населення й економічна діяльність мають все більше переміщуватися в міста. Однак при цьому підвищується антропогенний тиск на міські території. Тому з позицій гегелівської діалектики, щоб забезпечити розвиток і сільських (тезис), і міських (антитезис) територій, необхідним є синтез, зміст якого полягає у сталому розвитку і одних, i інших. Сталий розвиток, зокрема сільських територій, передбачає застосування найсучасніших технологій, розвиток сучасної інфраструктури, диверсифікацію і нарощуванням потенціалу сільської економіки i, зрештою, зростання чисельності сільського населення.

Діалектичний підхід до вирішення проблем сталого розвитку сільських територій в Україні певною мірою знайшов відображення у меті Програми. Згідно $з$ ним, «... забезпечуються зростання, диверсифікація і підвищення ефективності сільської економіки, зокрема, поза межами сільськогосподарського виробництва, стабілізація чисельності населення i збільшення тривалості життя, повна i продуктивна зайнятість працездатного населення, підвищення рівня і якості життя, раціональне використання і відтворення ... природно-ресурсного потенціалу сільських територій» [8].

Завдання Програми сформульовані відповідно до Державної стратегії регіонального розвитку за трьома напрямами: 1) диверсифікація підприємницької діяльності у сільській місцевості; 2) підвищення якості життя у сільській місцевості; 3) створення умов для соціального розвитку.

Відповідальними за виконання Програми визначено Мінагрополітики, Мінрегіон, інші центральні й регіональні органи виконавчої влади, а також органи місцевого самоврядування (за згодою).

Географія Програми охоплює всі регіони України, крім тимчасово окупованих територій Криму і Донбасу. 


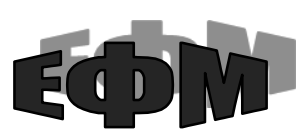

http://efm.vsau.org/

Фінансування Програми передбачено за ії напрямами та окремими проектами регіонального розвитку на грантових засадах. Проекти намічено відбирати на конкурсних засадах, а саме - згідно порядку, затвердженого наказом Мінрегіону від 18 травня 2017 р. Розміри грантів на проекти за першим напрямом передбачені в розмірі 12-48 млн грн, за другим - 3,6-12, за третім - 1,2-3,6 млн грн. Насамперед йдеться про міжнародні гранти, що зараховані до статей державного бюджету на основі Угоди про фінансування програми ENPI/2013/024-517 («Програма підтримки секторальної політики - Підтримка регіональної політики України» від 27 листопада 2014 р.) та Додаткової угоди до неї від 19 липня 2016 р. Термін виконання цієї Угоди починається з дати набрання нею чинності та закінчується через 96 місяців після цієї дати. Бенефеціарами Угоди від України виступають Мінрегіон та Мінекономрозвитку, від $С \mathrm{C}$ - Свропейська Комісія. Згідно Угоди, максимальний внесок до держбюджету з боку СС становить 55 млн євро.

Однак Програма є настільки важливою для майбутнього України, що для i реалізації доцільно залучати фінансові ресурси з усіх можливих, передбачених законами України, джерел. Значна частина проектів може бути реалізована за рахунок коштів Державного фонду регіонального розвитку (ДФРР), що становлять $1 \%$ від прогнозного обсягу доходів загального фонду держбюджету, коштів місцевих бюджетів та міжнародних інституцій. До речі, у 2016-2020 pp. в Україну має зайти багато коштів у вигляді міжнародної технічної допомоги на підтримку проектів децентралізації влади, в т. ч. у сільській місцевості: це кошти на проект $\mathrm{CC}$ «ULIT» загальною сумою 97 млн євро та проект CША «DOBRE» загальною сумою 50 млн дол. США [9, с. 13].

Одним із суттєвих недоліків Програми ми вважаємо відсутність необхідних передінвестиційних досліджень, принаймні загального характеру. Найбільш затребуваними є дослідження, спрямовані на обгрунтування того, які саме проекти регіонального розвитку (за напрямами Програми) має підтримувати держава. Тому спробуємо хоча б частково заповнити цю прогалину.

1. Диверсифікаџія підприємнииької діяльності у сільській місцевості. За цим напрямом Програми передбачається державна підтримка проектів регіонального розвитку, що забезпечують:

- диверсифікацію сільськогосподарського виробництва. Необхідність підтримки проектів $з$ диверсифікації (урізноманітнення) видів сільськогосподарського виробництва зумовлена тим, що мають місце такі тенденції: по-перше, відмічається подальше погіршення структури сільськогосподарського виробництва (порівняно 3 оптимальною структурою, що передбачає відносний паритет продукції рослинництва і тваринництва). На це, зокрема, вказує факт скорочення частки тваринництва у валовій продукції сільського господарства: 1990 р. - 48,5\%; 2000 р. - 38,5; 2010 р. - 36,1; 2013 р. 30,4; 2018 р. (без окупованих РФ

територій) - 17,9\%. У зв'язку з цим важливо проаналізувати динаміку часток окремих видів сільськогосподарського виробництва на основі економічних рахунків Держслужби статистики України (рис. 2). 


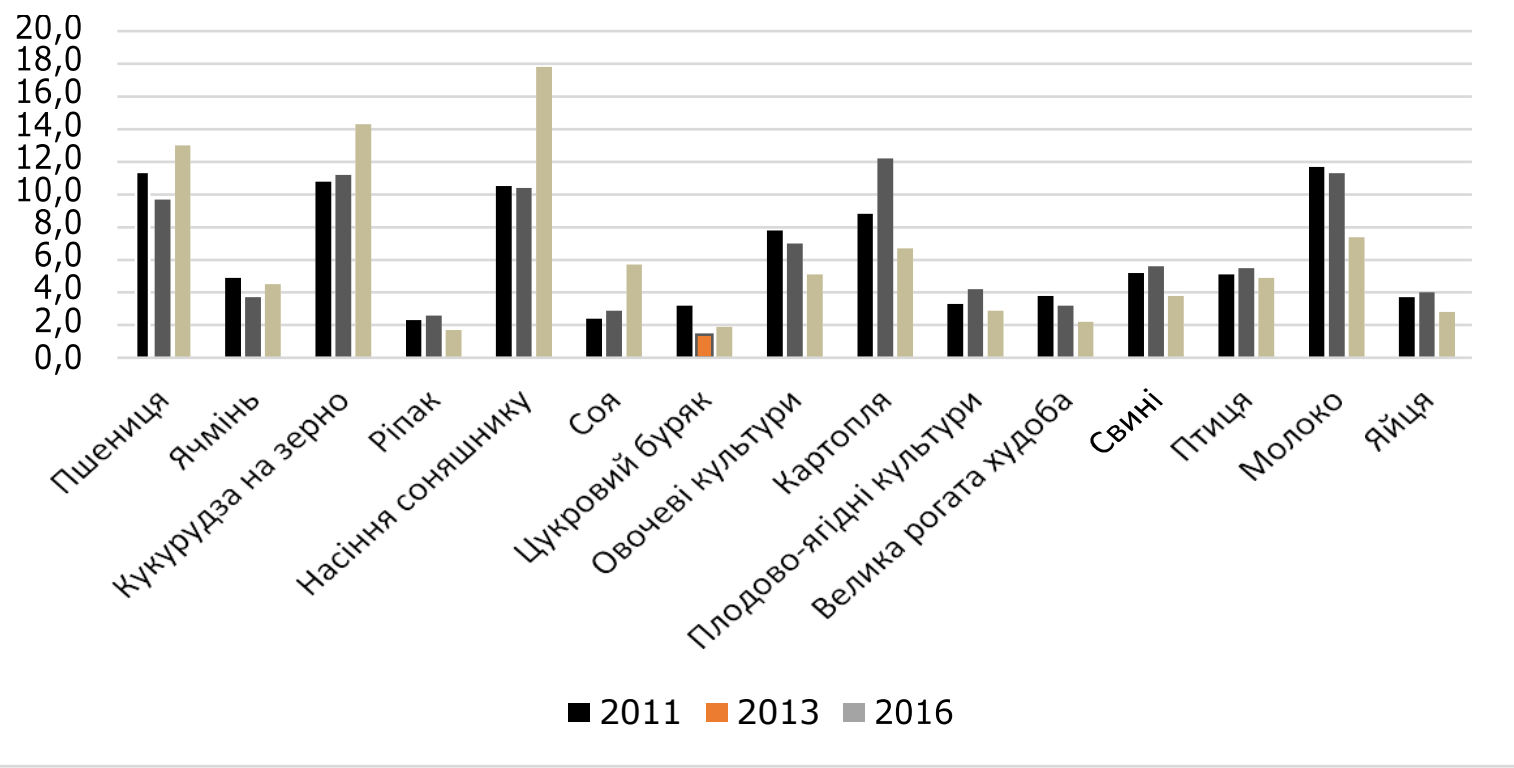

Рис. 2. Динаміка часток основних видів і груп сільськогосподарської продукції у загальному випуску у 2011-2016 рр., \%

Примітка: дані за 2016 р. наведено без урахування тимчасово окупованих територій Криму і Донбасу.

Джерело: сформовано автором за даними Державної служби статистики Украйни

Як видно з рис. 2, у 2011-2016 рр. із видів і груп продукції рослинництва найбільше зросла частка насіння соняшнику (з 10,5 до 17,8\% - на 7,3\%), кукурудзи на зерно (з 10,8 до 14,3\% - на 3,5\%) та сої (з 2,4 до 5,7\% - на 3,3\%), натомість суттєво скоротилася частка овочевих культур (з 7,8 до 5,1\% - на 2,7 \%) та картоплі (3 8,8\% до $6,7 \%$ - на 2,1\%). За цей же період із видів і груп продукції тваринництва тільки частка птиці залишилася на рівні, близькому до 5\%, водночас сильно скоротилася частка молока (з 11,7 до 7,4\% - на 4,3\%) і суттєво - великої рогатої худоби (з 3,8 до 2,2\% на 1,6\%) та свиней (з 5,2 до 3,8 \% - на 1,4\%) [10;12].

При цьому загальна структура виробництва сільськогосподарської продукції також сильно змінилася. Ступінь їі трансформації можна оцінити на основі модифікованого нами коефіиієнта Хечмена $\left(I_{H A C}\right)$ :

$$
\mathrm{I}_{\mathrm{HAC}}=\frac{1}{\sum_{i=1}^{m}\left(\frac{s_{\bar{i}}^{N}}{s_{\bar{i}}}\right) * S \frac{N}{i}} \quad\left(0 \leq \mathrm{I}_{\mathrm{HAC}} \leq 1\right)
$$

де $S \frac{N}{i}, S \frac{\mathrm{E}}{i}$ частки $i$-х видів і груп сільськогосподарської продукції в структурі її виробництва, відповідно, досліджуваного і базового років.

Сенс варіації $I_{\text {HАC }}$ в інтервалі [0,1] такий: при його значенні, що дорівнює одиниці, структура виробництва сільськогосподарської продукції у досліджуваний період повністю збігається 3 аналогічною структурою базового року, а нульове значення коефіцієнта свідчить про те, що ці структури абсолютно різні.

Розрахунки $I_{H A C}$ показали, що структура сільськогосподарського виробництва України найбільше змінилася після окупації РФ частини території України. Якщо значення $I_{\text {HАC }}$ (у 2011 р. його значення прийняте за одиницю) у 2013 р. становило 0,966, то у 2016 р. - тільки 0,862;

по-друге, практикується гіпертрофована спеціалізація та звуження спектру сільськогосподарських видів діяльності на рівні окремих сільгосппідприємств, 


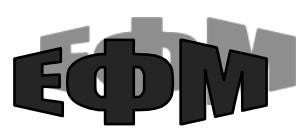

http://efm.vsau.org/ причому як малих і середніх (особистих селянських і фермерських господарств), так i великих (агрохолддингів). У контексті сталого розвитку сільських територій особливо небажаною є вузька спеціалізація останніх на вирощуванні зернових і технічних культур, що об'єктивно призводить до скорочення чисельності працівників та основного поголів'я худоби в розрахунку на 100 га сільськогосподарських угідь, наприклад, до 5 працівників у ТОВ «Трайгон Фармінг Харків» проти 150 у господарствах населення (табл. 1).

\section{Чисельність працівників і поголів'я худоби у розрахунку на площу сільськогосподарських угідь в агрохолдингах у 2016 р.}

\begin{tabular}{|c|c|c|c|}
\hline Назви агрохолдингів & $\begin{array}{c}\text { Площа } \\
\text { сільгоспугідь, } \\
\text { тис. га }\end{array}$ & $\begin{array}{c}\text { Чисельність } \\
\text { працівників у } \\
\text { розрахунку на } \\
1000 \text { га } \\
\text { сільгоспугідь, } \\
\text { осіб }\end{array}$ & $\begin{array}{c}\text { Поголів'я худоби } \\
\text { у } \\
\text { розрахунку на } \\
1 \text { га сільгоспугідь, } \\
\text { умов. голів }\end{array}$ \\
\hline ГК «Укрлендфармінг» & 654 & $\ldots$ & 1,06 \\
\hline $\begin{array}{l}\text { ПАТ «Миронівський } \\
\text { хлібопродукт» }\end{array}$ & 360 & 83 & $15,3^{*}$ \\
\hline ПАТ «Мрія Агрохолдинг» & 320 & 19 & - \\
\hline Агропромхолдинг «Астарта-Київ» & 245 & 57 & 0,13 \\
\hline HarvEast Holding & 197 & 22 & 0,09 \\
\hline $\begin{array}{l}\text { 3АТ «Індустріальна молочна } \\
\text { компанія» }\end{array}$ & 136,7 & 26 & 0,06 \\
\hline Agro Generation & 120 & 12 & - \\
\hline ГК «Приват-Агрохолдинг» & 116 & $\ldots$ & 0,03 \\
\hline ТОВ СП «Нібулон» & 81 & 59 & 0,07 \\
\hline Agrokultura AB & 68 & 13 & 0,00 \\
\hline ТОВ «Трайгон Фармінг Харків» & 48 & 5 & - \\
\hline
\end{tabular}

*Головний напрям виробництва компанії - промислове виробництво курятини Джерело: [10, с. 40]

Це також $\epsilon$ однією 3 головних причин виснаження грунтів - через недотримання сівозміни та внесення недостатньої кількості органічних добрив (гною, компостів тощо). Крім того, для отримання високих врожаїв та високих прибутків, агрохолдинги використовують генну модифікацію та хімізацію землі, що становить пряму загрозу здоров'ю населення;

по-третє, мало практикується розвиток нових видів сільськогосподарського виробництва, наприклад, розведення страусів (звичайно, за умови, що це економічно вигідно).

Отже, держава в першу чергу має підтримувати проекти, які: а) сприяють оптимізації структури сільськогосподарського виробництва (перевага має віддаватися проектам в галузі тваринництва); б) є новими для сільськогосподарської діяльності; в) формують потужний ланцюг доданої вартості; г) є інноваційними та орієнтованими на досягнення світових стандартів якості сільськогосподарської, зокрема органічної, продукції; д) є трудомісткими, що дозволить агропідприємствам створювати нові робочі місця, працівникам - мати гідну заробітну плату, а населенню - затримуватися на селі; е) $є$ екологічно безпечними. Але особливо важливими є проекти, у яких враховуються декілька чи усі ці характеристики, як, наприклад, у проекті зі створення аграрного кластера у Вінницькій області вартістю 12 млн грн за рахунок різних джерел фінансування. 
Диверсифікація сільськогосподарського виробництва зазвичай поглиблюється, якщо сільгосппродукція спрямовується на переробні підприємства. Це сприяє зростанню кількості робочих місць у сільській місцевості, формуванню ефективних ланцюгів доданої вартості тощо. Тому ми виступаємо за те, щоб для кожного виду сільськогосподарської сировини на законодавчому рівні було встановлено відсоток, що підлягає обов'язковій переробці. У цьому випадку різко зросте значимість і необхідність у державній підтримці проектів із поглибленої переробки зерна, картоплі, цукрових буряків та інших культур, зокрема 3 виробництва біоетанолу [11, с. 14]. До речі, такі проекти уже реалізуються. Так у 2017p. у Вінницькій області на ДП «Тростянецький спиртовий завод» реалізовано проект загальною вартістю 50 млн грн зі створенням 100 робочих місць, а на Гайсинському спиртзаводі, що належить ТОВ «Корпорація СКІФ-96», проект загальною вартістю 210 млн грн зі створенням 70 робочих місць. I хоча ці проекти реалізовані не в селах, а в райцентрах, їх мультиплікативний вплив на розвиток сільських територій є суттєвим;

- розвиток альтернативних видів економічної діяльності. Суттєво змістити економічну діяльність 3 великих міст у сільську місцевість без розвитку там альтернативних (відмінних від агропромислових) видів діяльності практично неможливо. Однак провести такий просторовий зсув економічної діяльності за рахунок тільки прискореного розвитку народних ремесел, різних промислів, альтернативної енергетики, екологічного (зеленого), сільського та інших видів туризму, як це передбачається в Програмі (навіть за умови створення відповідних кластерів у сільській місцевості), нам видається малоймовірним. Необхідним є перенесення до сільської місцевості високотехнологічних видів діяльності. I рух у цьому напрямку в Україні, хоча й у незначних масштабах, уже розпочався. Так з 10 травня 2017 р. у Піщанському та Чечельницькому районах Вінницької області ТОВ «Поларіснет», яке представляє інтереси члена королівської родини Саудівської Аравії, реалізується проект із будівництва сонячних електростанцій вартістю 30 млн євро.

Характерним прикладом альтернативної індустріалізації сільської місцевості може слугувати й реалізація проекту з будівництва автозаводу (ПрАТ «Сврокар») у с. Соломоново Ужгородського району на Закарпатті з виробництва автомобілів Škoda. I хоча цей проект було реалізовано за кошти німецького концерну Volkswagen, Українська держава стимулює розширення інвестиційної діяльності на автозаводі, замовивши у 2017 p. 400 хетчбеків Škoda Rapid для Національної поліції. Звичайно, реалізовувати в сільській місцевості проекти 3 альтернативних видів економічної діяльності, що передбачають велику кількість нових робочих місць, досить складно тому, що трудові ресурси територіально розпорошені, а рівень їхньої кваліфікації значно нижчий, ніж у містах. У цій ситуації великі сподівання ми покладаємо на проекти 3 формування кластерів, що охоплюють і сільську місцевість. Вони $\epsilon$ сучасним варіантом розсіяної мануфактури, але вигідно відрізняються від тієї за інноваціями, формами співпраці учасників (у т. ч. і в циклах глобального виробництва) та продуктивністю. Прикладами таких кластерів можуть слугувати індустріальні округи в Італії (іх близько 200);

- розвиток органічного сільськогосподарського виробництва. Сільськогосподарська продукція, яка складає основу харчового раціону людей, має нести користь їхньому здоров'ю. На жаль, з переходом до ринкових відносин, при майже повному відстороненню держави від контрольних функцій на ринок викинуто масу неякісної сільськогосподарської продукції. У цій ситуації одним із важливих 


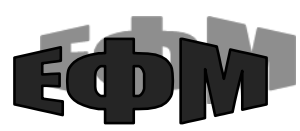

http://efm.vsau.org/

напрямків розвитку аграрної сфери є створення й реалізація проектів 3 розвитку органічного (природного) агровиробництва. В Україні його розвиток довгий час гальмувався ціновим паритетом органічної і неорганічної агропродукції, тоді як, наприклад, у США ціна домашньої курятини перевищує ціну промислової в 10-15 разів. Виправленню ситуації може сприяти прийняття Верховною Радою Закону України «Про основні принципи та вимоги до органічного виробництва, обігу та маркування органічної продукції» від 2 серпня 2018 р., що вступає в дію з 2 серпня 2019 р. Реалізації багатьох проектів з розвитку виробництва органічної продукції може сприяти й те, що іiі світовий ринок демонструє позитивну динаміку, а перспективний для України ринок СС складає 41\% від світового [12];

- розвиток переробних $i$ сервісних підприємств на засадах кооперації. Доцільність розвитку таких підприємств зумовлена необхідністю стабілізації обсягів виробництва і реалізації агропродукції, збільшення доходів учасників кооперативних об'єднань, розвитку сільських територіальних громад. Суттєву допомогу в реалізації проектів із формування сільськогосподарських кооперативів в Україні надають європейські міжнародні донорські організації. За їх участю у Вінницькій, Львівській, Херсонській та Черкаській областях реалізовано 6 таких проектів. А завдяки проекту ЄС «Підтримка політики регіонального розвитку в Україні» за 2013-2016 рр. було створено понад 50 кооперативів різних видів діяльності. На це витрачено 14,1 млн грн, 3 яких 10,9 млн - кошти європейських організацій [13, с. 70].

2. Підвищення якості життя у сільській місцевості. За цим напрямом Програми необхідною є державна підтримка проектів регіонального розвитку 3 метою:

- створення (поліпшення) умов для повернення молоді у сільську місиевість. Молодь із села мігрувала завжди: для того, щоб повніше зреалізувати себе, в пошуках кращого життя тощо. Але в останні десятиліття масштаби відтоку молоді 3 села такі, що через деякий час це може призвести до заміни сільської поселенської мережі хутірською. 3 позицій діалектичного підходу до сталого розвитку сільських і міських територій - це небажана тенденція. Єдиний шанс іiі зупинити або пом'якшити - створити комфортні умови для проживання на селі, максимально наблизити їх до умов у містах. Тому відповідні проекти мають бути спрямовані на створення додаткових робочих місць 3 гідною оплатою праці (див. вище), будівництво комфортабельного житла для молодих фахівців та поліпшення усіх видів інфраструктури;

- оліпшення інженерної інфраструктури сільської місцевості, яка включає такі іiі види - дорожньо-транспортну, мереж зв'язку, енергетичну та житловокомунальну.

Більшість проектів із поліпшення дорожньо-транспортної інфраструктури на селі передбачають капітальний ремонт дорожнього покриття та облаштування тротуарів. Прикладом може слугувати проект вартістю 1,3 млн грн з облаштування тротуарів у с. Крюківщина Києво-Святошинського району Київської області, реалізований у 2017 р. за кошти ДФРР та місцевого бюджету.

Розвиток мереж зв'язку в сільській місцевості значною мірою пов'язаний 3 реалізацією проектів, що передбачають розширення доступу до швидкісного (широкосмугового) Інтернету на основі технології LTE та 4G мобільного зв'язку. Їх реалізація сприятиме подоланню «цифрового розриву» між міськими і сільськими територіями (30\% міських мешканців мають доступ до швидкісного Інтернету, а сільських - тільки 5 \%). Для підтримки проектів Кабмін має намір створити окремий 
фонд, акумулювавши в ньому кошти від продажу 31 січня 2018 р. ліцензій компаніям «Київстар», Vodafone та lifecell на радіочастотний ресурс у діапазоні 2,6 МГц на майже 2,5 млрд грн [14].

Для зміцнення енергетичної інфраструктури в сільській місцевості особлива увага має приділятися реалізації проектів з поліпшення енергопостачання, освітлення вулиць тощо. Прикладом може слугувати проект із капітального ремонту мереж вуличного освітлення у с. Парпурівці та с. Майдан-Чапельський Хижинецької сільської ради Вінницького району вартістю 2 млн грн за кошти державного та місцевого бюджетів.

На підвищення енергоефективності громадських будівель у сільській місцевості націлений проект «Енергоефективність у громадах II», що реалізується у 2017-2020 pp. за замовленням Федерального міністерства економічного співробітництва та розвитку Німеччини та посередництва Мінрегіону України.

Поліпшенню житлово-комунальної інфраструктури щонайбільше сприяє реалізація проектів із підвищення енергоефективності помешкань сільських жителів, обладнання квартир водопроводом, каналізацією та гарячим водопостачанням. Успішним прикладом може слугувати реалізація проекту (у 2018 р.) з будівництва мереж водопостачання в с. Дубові Махаринці Козятинського району вартістю 1,8 млн грн за кошти сільської ради та приватних підприємців;

- поліпшення інформаційно-освітньої та соціальної інфраструктури сільської місиевості. Основу інформаційно-освітньої інфраструктури на селі складають дорадчі служби та окремі дорадники. Їхня діяльність спрямована на підвищення рівня практичних знань сільськогосподарських товаровиробників, сільського населення та представників місцевої влади. Ці знання можуть виступати важливим засобом розвитку сільських територіальних громад та поширення інновацій. На жаль, в Україні мережа дорадчих служб ще не створена, тому при реалізації проекту з ії створення доцільно врахувати досвід формування такої мережі («Extension») у США [4, с. 91].

Щодо соціальної інфраструктури (освіта, охорона здоров'я, культура, фізична культура й спорт, торгівля й громадське харчування, побутове обслуговування населення тощо), то у більшості сіл вона слаборозвинена або переживає період занепаду. Однією з причин цього став неефективний механізм роздержавлення іiі об'єктів, зокрема передачі з державної до комунальної власності (згідно постанови Кабміну від 2 грудня 1996 р.). Нині в сільській місцевості найкраще розвинені об’єкти торгівлі, більшість із яких знаходяться у приватній власності. Ще «тримаються на плаву» освітні й медичні заклади і то тільки тому, що органи місцевого самоврядування отримують відповідні субвенції з державного бюджету. Однак реалізація реформи децентралізації передбачає поступову передачу цих закладів на утримання об'єднаних територіальних громад (ОТГ). Це з великою ймовірністю стимулюватиме процес згортання їхньої мережі, тому що більшість ОТГ є фінансово неспроможними. I навіть реалізація окремих проектів, зокрема у Вінницькій області, з будівництва шкіл (у с. Гопчиця Погребищенського району вартістю 15,3 млн грн), чи з реконструкції фельдшерсько-акушерських пунктів (у с. Лелітка Хмільницького району), не впливатиме кардинально на поліпшення стану освітньої та медичної інфраструктури в сільській місцевості. Хоча певні сподівання ми покладаємо на реалізацію проектів, що передбачають розвиток телемедицини, державно-приватного партнерства у галузі медицини тощо (згідно Закону України «Про підвищення доступності та якості медичного обслуговування у сільській місцевості» від 14 листопада 2017 р.). 


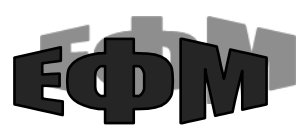

http://efm.vsau.org/

Для підтримки фізичного здоров’я сільських жителів необхідною є реалізація проектів зі створення спортивних об'єктів в системі шкільного й дитячо- юнацького спорту та в мережі центрів «Спорт для всіх». Прикладом може слугувати реалізація проектів із будівництва спорткомплексу у с. Іванів Калинівського району Вінницької області вартістю 11,4 млн грн, в т. ч. 10,4 млн грн за рахунок коштів ДФРР, та будівництва шкільного футбольного поля із штучним покриттям у с. Городківка Крижопільського району орієнтовною вартістю 1,5 млн грн;

- поліпшення екологічної інфраструктури. Найбільше ця проблема зачіпає села і селища поблизу великих міст, де є полігони побутових відходів, наприклад такі, як Підгірці біля Києва, Грибовичі біля Львова, Стадниця біля Вінниці, та станції аерації - на околицях Києва (у Бортничах), Львова, Вінниці (у Сабарові). У всіх них необхідними $\epsilon$ реконструкція або введення нових об'єктів екологічної інфраструктури, зокрема сміттєпереробних заводів та новітніх станцій аерації. Так у Львові після закриття Грибовицького полігону і проведення необхідних тендерних процедур уже у 2019 р. розпочнеться реалізація проекту 3 будівництва сміттєпереробного заводу орієнтовною вартістю 25 млн євро. У цьому ж році за інвестиційної підтримки Світового банку реконструкції і розвитку розпочнеться реалізація проекту з реконструкції очисних споруд у Сабарові (вартістю 2 млн євро). Щодо реалізації проектів із сортування та переробки твердих побутових відходів на сільських територіях, то вона має стати масовою, тому що згідно Закону України «Про відходи» від 5 березня 1998 р. (в редакції від 4 жовтня 2018 р.), всі відходи, перед тим як попасти на захоронення, мають бути перероблені. У Вінницькій області такі проекти передбачається реалізувати на території багатьох сільських i селищних рад, зокрема Серебрійської Могилів-Подільського району (вартістю 16 млн грн), Теплицької, Оратівської та інших.

Для збереження природної спадщини України активізувався процес створення нових об'єктів природно-заповідного фонду, зокрема в рамках реалізації українсько-німецького проекту «Підтримка природно-заповідних територій в Україні» вартістю 14 млн євро, що фінансується за рахунок Кредитної установи для відбудови (KfW) із Німеччини.

3. Створення умов для сочзільного розвитку. Цей напрям Програми передбачає державну підтримку проектів регіонального розвитку, спрямованих на:

- планування сільського розвитку. Таке планування має декілька напрямів: 1) планування мережі сільських територіальних громад; 2) просторове планування сільських територій; 3) стратегічне планування розвитку сільських територіальних громад.

Перший напрям передбачає планування території сільських і селищних рад та ОТГ, сільських районів згідно базових положень Закону України «Про Генеральну схему планування території України» в редакції від 18 листопада 2012 р. Його імперативом $\epsilon$ те, що кожен громадянин країни, незалежно від місця проживання, повинен мати рівні умови доступу до об'єктів соціально-культурного обслуговування. У зв'язку з цим (на чому в Законі наголошується в розділі 4) дуже важливо сформувати системи розселення, починаючи від первинних, що максимально наближені до оптимальних. Вони, як слідує з теорій центральних місць В. Кристаллера та «економічних ландшафтів» А. Льоша, повинні мати гексагональну форму: в центрі знаходиться найбільше село або селище, навколо нього - шість менших сіл. Бажано, щоб у такій системі проживало не менше 5 тис. осіб, що дозволяє утримувати у її центрі середню школу та амбулаторію, а в окремих селах - 


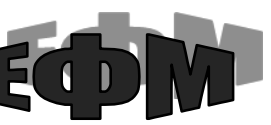

http://efm.vsau.org/

базову чи початкову школу, фельдшерсько-акушерський пункт тощо. Первинні системи розселення, згідно теорії, мають формувати наступні за рангом, також гексагональні, системи розселення: районні (наприклад, Ямпільську, з населенням понад 35 тис. осіб, але не більше 150 тис., що відповідатиме територіальній одиниці рівня LAU за стандартом територіального поділу NUTS, прийнятому в $\mathrm{CC}$ ), окружні, обласні або регіональні та макрорегіональні.

Однак за Законом України «Про добровільне об’єднання територіальних громад» від 5 лютого 2015 р., декількох законів, що вносять зміни до нього, та Постанови Кабінету Міністрів України «Про затвердження Методики формування спроможних територіальних громад» від 8 квітня 2017 р. у сільській місцевості передбачається формування ОТГ, що не вписуються в класичну теорію розселення людей. На це вказують Перспективні плани формування територій спроможних (об'єднаних) територіальних громад, що затверджуються обласні радами і погоджуються з Кабінетом Міністрів України. Згідно з ними, в адміністративних районах передбачається сформувати в середньому не по 7 низових систем розселення i, відповідно, ОТГ, як у Польщі, а по 3-4 (а подекуди й одну, що різко скорочує кількість мікро-полюсів зростання в сільській місцевості), нинішні адміністративні райони ліквідувати, а замість них створити укрупнені райони (фактично округи). Відповідно, намічається переформатування мережі об'єктів соціальної інфраструктури. Середні школи й амбулаторії обов'язково мають бути переважно в центрах ОТГ, районні лікарні передбачається ліквідувати, а вторинну медичну допомогу надавати тільки в окружних центрах. При цьому прихильники освітньої, медичної та інших реформ не дають відповіді на життєво важливі питання: як, наприклад, породіллю зі складною патологією за 15-20 хвилин доставити з Шаргородського району у Могилів-Подільський (а це близько 60 км по дорозі сумнівної якості), якщо у Шаргороді буде закрито районну лікарню з її пологовим відділенням.

На швидку реалізацію планів формування територій сільських ОТГ, реалізацію заходів в рамках освітньої і медичної реформи в сільській місцевості націлені десятки проектів у кожній області. Найбільш масовими є проекти з розвитку інфраструктури сільських ОТГ та сільської медицини, що фінансуються з державного бюджету за рахунок відповідних субвенцій. Тільки у Вінницькій області за рахунок субвенції на формування інфраструктури 34 ОТГ на реалізацію 79 проектів (більшість із яких сільські та селищні) у 2018 році було виділено 53,8 млн грн.

Навіть попередній аналіз можливих наслідків реформи децентралізації, освітньої та медичної реформ вказує на те, що результатом їх проведення буде подальша «зачистка» сільської поселенської мережі (за роки незалежності в Україні уже знято з обліку 40 селищ і 601 село). Довершити справу має земельна реформа 3 iï вільним або прихованим (через незаконну передачу в комунальну власність) продажем землі. Тим більше, що власників агрохолддингів, особливо зарубіжних, які реально мають кошти для купівлі земельних ділянок і масивів, не сильно турбують проблеми розвитку сільських територій в Україні, тому вони й далі будуть вирощувати високодохідні культури з малими працезатратами, а це прямий шлях до обезлюднення сіл. Отже, держава має запропонувати таку (орендну) модель ринку земель сільськогосподарського призначення (зі збереженням безоплатних земельних паїв для жителів сільської місцевості, учасників Антитерористичної операції та Операції об'єднаних сил), яка б стимулювала землекористувачів до тих видів діяльності, які щонайбільше необхідні для розвитку сільських територій.

Другий напрям планування сільського розвитку (з просторового планування 


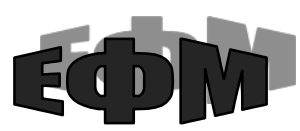

http://efm.vsau.org/ сільських територій) базується на ДБН Б.2.2-12:2018. Тому відповідні проекти пов'язані 3 плануванням зон житлової і громадської забудови, виробничих сільськогосподарських виробничих територій, а також розміщення об'єктів транспортної, інженерної та соціальної інфраструктури. Цікаво те, що ДБН Б.2.2-12:2018 уже налаштований (в п. 7.6.4) на розрідження сільської поселенської мережі, оскільки визначає особливості функціонального зонування території за хутірської системи розселення.

Третій напрям планування сільського розвитку (зі стратегічного планування розвитку сільських територіальних громад) має особливе значення в умовах проведення реформи децентралізації. Він передбачає розробку стратегічних планів сталого розвитку сільських ОТГ. Такі плани мають відповідати стратегіям розвитку відповідних регіонів та Державній стратегії регіонального розвитку. Зазвичай вони орієнтують представників сільських ОТГ на розвиток місцевої економіки, розвиток людського капіталу та збереження довкілля. Саме планування сталого розвитку сільських ОТГ базується на визначенні проектів стратегічного характеру, зокрема оріснтованих на зростання власних доходів громад, та прогнозі надходжень фінансових ресурсів із різних джерел, необхідних для їх реалізації:

- розвиток партнерства бізнесу та влади. У реалізації багатьох проектів можуть бути зацікавлені представники бізнес-спільноти, тому їх доцільно реалізовувати на засадах співпраці бізнесу та влади. Показовим прикладом такої співпраці може слугувати розробка і реалізація проекту 3 будівництва лінії 3 сортування сміття на полігоні твердих побутових відходів в селищі Оратів Вінницької області, на який виділено 1,5 млн грн із державного бюджету, 200 тис. грн із обласного бюджету, 400 тис. грн із селищного бюджету і 100 тис. грн за рахунок коштів суб' єктів господарювання;

- активізаиію сільського розвитку за результатами отриманої підтримки. Підтримка розвитку сільських територій з боку усіх зацікавлених сторін має конкретні вияви у вигляді кількості та вартості реалізованих проектів відповідно до напрямів Програми.

За кожним напрямом передбачається встановлювати очікувані результатита показники виконання Програми. Ключовими показниками визначено: за першим напрямом - кількість нових видів продукції у межах відповідної території, що не пов'язані з традиційним виробництвом на даній території; другим - кількість нових або розширення існуючого переліку послуг, спрямованих на покращення життя населення у сільській місцевості; третім - кількість осіб, які підвищили свою спроможність щодо сільського розвитку. Реалізацію проектів регіонального розвитку за кожним напрямом мають підтверджувати й інші показники, однак кількісно визначити деякі з них не є можливим. Так незрозуміло, яким чином можна визначити, наприклад, показник забезпечення сталості надання послуг.

Звичайно, без точно визначеної системи показників дати більш-менш точні оцінки можливостей виконання Програми за напрямами і проектами регіонального розвитку досить складно, хоча більшість регіональних програм таку можливість дають. Наприклад, «Державна цільова програми розвитку українського села на період до 2015 р.», схвалена постановою Кабміну від 19 вересня 2007 р., була виконана на $67 \%$ [3, с. 202].

Проте, на нашу думку, це не має принципового значення. Що 3 того, що за показниками регіональної програми «Поділля» можна було чітко визначити ступінь іiі виконання, коли абсолютна більшість проектів, наприклад, із будівництва чотирьох нових цукрових заводів у Вінницькій області, не були реалізовані. Тому значно важливіше, щоб якомога більше проектів, дійсно важливих для сталого розвитку сільських територій, були реалізовані, а не тільки верифіковані за ступенем їх виконання. Водночас ми вважаємо, що 


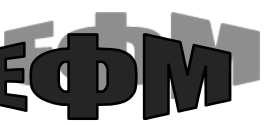

http://efm.vsau.org/

конче необхідним є моніторинг виконання окремих проектів та вчасне коригування Програми згідно передінвестиційних досліджень. Важливо також, щоб проекти, що реалізуються в межах програми «Сільський розвиток» були узгоджені $з$ проектами інших програм, як загальнодержавних, наприклад, із розвитку сільської телемедицини, так і власне регіональних (що розробляються регіональними та місцевими органами влади). Координаторами узгодження в регіонах усіх проектів за різними програмами регіонального розвитку мають виступати департаменти економічного розвитку облдержадміністрацій та міністерство економічного розвитку АР Крим (після її деокупації).

Висновки. Обмежені можливості ринкового механізму щодо забезпечення населення суспільними товарами та регулювання екстерналій потребують державного регулювання економіки та суміжних із нею сфер - життєдіяльності людей та природокористування. Важливим інструментом регулювання та взаємодії цих сфер у контексті сталого розвитку різних територій, зокрема сільських, $\epsilon$ регіональне програмування. В Україні у зв'язку із загостренням проблем сталого сільських територій важливе значення має розробка і реалізація регіональної програми «Сільський розвиток». Така Програма, згідно концептуальних і законодавчих засад державної регіональної політики та основних напрямів «Державної стратегії регіонального розвитку на період до 2020 року», була розроблена і представлена Мінрегіоном, але у досить схематичному вигляді. Отже, вона потребує поглибленого наукового аналізу, доопрацювання концептуальної схеми та конкретизації. Акцент в подальших дослідженнях слід зробити на передінвенстиційному обгрунтуванні найважливіших проектів регіонального розвитку (за ключовими напрямами Програми), які першочергово мають одержати державну підтримку.

\section{Список використаних джерел}

1. Жерибор Л.Л., Судак Г.В. Програмування соціально-економічного розвитку сільських територій. Вісник Житомирського начіонального агроекологічного університету. 2011. № 2(2). С. 33-41.

2. Ксенофонтов М.М. Особливості програмування соціально-економічного розвитку агропромислового виробництва та сільських територій. Bicник Хмельницького національного університету. Сер. Економічні науки. 2009. № 6, т. 1. C. 260-263.

3. Маленька I.М. Фінансова підтримка сільського господарства України: програмний аспект. Глобальні та нащіональні проблеми економіки. 2015. Вип. 6. С. 200-205. URL: http:/global-national.in.ua/archive/6-2015/40.pdf (дата звернення: 16.03.2019).

4. Недбалюк О.П. Міжнародний досвід організації розвитку сільських територій та можливості його застосування в Україні. Економіка і суспільство. 2017. Вип. 9. С. 89-94. URL: http://www.economyandsociety.in.ua/journal/9_ukr/14.pdf (дата звернення: 16.03.2019).

5. Нелеп В.М., Фурсенко М. І. Програмування розвитку сільських територій і бюджети сільських рад. Економіка АПК. 2005. № 4. С. 107-112.

6. Rural Development in the European Union Statistical and Economic Information / European Commission Directorate-General for Agriculture and Rural Development. 2013. URL: http://ec.europa.eu/agriculture/statistics/rural-development /2013/ full-text_en.pdf (дата звернення: 22.03.2019).

7. Державна стратегія регіонального розвитку України на період до 2020 року : затв. постановою Кабінету Міністрів України від 6 серп. 2014 р. № 385. URL : http://zakon2.rada.gov.ua/laws/show/385-2014-п (дата звернення: 22.03.2019).

8. Деякі питання реалізації у 2018-2020 роках Державної стратегії 


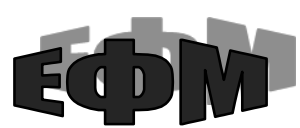

http://efm.vsau.org/

регіонального розвитку на період до 2020 року : постанова Кабінету Міністрів України від 12 вер. 2018 р. № 733. URL: http://cg.gov.ua/ web_docs/1/2014/ 11/docs/\%D0\%BF\%D0\%BE\%D1\%81\%D1\%82\%D0\%B0\%D0\%BD\%D0\%9A\%D0\%9C \%D0\%A3733.pdf (дата звернення: 26.03.2019).

9. Ткачук А., Кашевський В., Мавко П. Стратегічне планування у громаді (навчальний модуль). Київ : ІКЦ «Легальний статус», 2016. 96 с.

10. Попова О.Л. Основи гармонізації аграрного і сільського розвитку в сучасній аграрній політиці. Економіка України. 2014. №10. С. 32-43.

11. Калетнік Г.М. Розвиток ринку біопалив в Україні. Біоенергетика. 2013. № 1. C. 11-16.

12. Ковальова О. В. Щодо напрямів розвитку органічного виробництва сільськогосподарської продукції в Україні : аналіт. зап. Національний інститут стратегічних досліджень : веб-сайт. URL: http://www.niss.gov.ua/articles/1292/ (дата звернення: 29.03.2019).

13. Драбовський А.Г. Проблеми та перспективи розвитку окремих кооперативних форм господарювання в українській економіці. Вісник Волинського інституту економіки та менеджменту. 2018. Вип. 21. С. 64-73.

14. Бурдига I. Нове покоління на зв'язку: коли в Україні запрацює 4G. Громадське телебачення: веб-сайт. 2018. 1 лют. URL: https://hromadske.ua/posts/koliv-ukraini-zapracyue-4g (дата звернення: 04.04.2019).

\section{References}

1. Zherybor, L.L. \& Sudak, H.V. (2011). Prohramuvannia sotsialnoekonomichnoho rozvytku silskykh terytorii [Programming of Socio-Economic Development of Rural Territories]. Visnyk Zhytomyrskoho natsionalnoho ahroekolohichnoho universytetu - Bulletin of Zhytomyr National Agroecological University, 2(2), 33-41 [in Ukrainian].

2. Ksenofontov, M.M. (2009). Osoblyvosti prohramuvannia sotsialno-ekonomichnoho rozvytku ahropromyslovoho vyrobnytstva ta silskykh terytorii [Features of programming of socio-economic development of agro-industrial production and rural areas]. Visnyk Khmelnytskoho natsionalnoho universytetu. Ser. Ekonomichni nauky - Bulletin of the Khmelnytsky National University. Ser. Economic Sciences, 6(1), 260-263 [inUkrainian].

3. Malenka, I.M. (2015). Finansova pidtrymka silskoho hospodarstva Ukrainy: prohramnyi aspekt [Financial Support to Agriculture in Ukraine: Programmatic Aspect]. Hlobalni ta natsionalni problemy ekonomiky - Global and national problems of the economy, 6, 200-205. Retrieved from http://global-national.in.ua/archive/6-2015/40.pdf [in Ukrainian].

4. Nedbaliuk, O. P. (2017). Mizhnarodnyi dosvid orhanizatsii rozvytku silskykh terytorii ta mozhlyvosti yoho zastosuvannia $\mathrm{v}$ Ukraini [International experience of organization of development of rural territories and possibilities of its application in Ukraine]. Ekonomika i suspilstvo - Economics and Society, 9, 89-94. Retrieved from http://www.economyandsociety.in.ua/journal/9_ukr/14.pdf [in Ukrainian].

5. Nelep, V.M. \& Fursenko, M.I. (2005). Prohramuvannia rozvytku silskykh terytorii i biudzhety silskykh rad [Programming of rural development and budgets of village councils]. Ekonomika APK - Economy of agroindustrial complex, 4, 107-112 [in Ukrainian].

6. Rural Development in the European Union Statistical and Economic Information (2013). European Commission Directorate-General for Agriculture and Rural Development. Retrieved from http://ec.europa.eu/agriculture/statistics/rural-development/ 2013/ full-text_en.pdf.

7. Derzhavna stratehiia rehionalnoho rozvytku Ukrainy na period do 2020 roku : zatv. postanovoiu Kabinetu Ministriv Ukrainy vid 6 serp. 2014 r. № 385 [The state strategy 


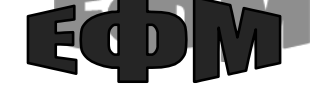

http://efm.vsau.org/

of regional development of Ukraine for the period up to 2020 : approved the decision of the Cabinet of Ministers of Ukraine dated August 6. 2014 No. 385.]. Retrieved from http://zakon2.rada.gov.ua/laws/show/385-2014-p [in Ukrainian].

8. Deiaki pytannia realizatsii u 2018-2020 rokakh Derzhavnoi stratehii rehionalnoho rozvytku na period do 2020 roku: postanova Kabinetu Ministriv Ukrainy vid 12 ver. 2018 r. № 733. [Some issues of realization in the years 2018-2020 of the State Strategy for Regional Development for the period till 2020: the resolution of the Cabinet of Ministers of Ukraine dated 12 September 2018, No. 733]. Retrieved from http://cg.gov.ua /web_docs /1/2014/11/docs/\%D0\%BF\%D0\%BE\%D1\%81\%D1\%82\%D0\%B0\%D0\%BD\%D0\%9A\% D0\%9C\%D0\%A3733.pdf [in Ukrainian].

9. Tkachuk, A., Kashevskyi, V. \& Mavko P. (2016). Stratehichne planuvannia u hromadi (navchalnyi modul) [Strategic Planning in the Community (curriculum module)]. Kyiv: IKTs «Lehalnyi status» [in Ukrainian].

10. Popova, O. L. (2014). Osnovy harmonizatsii ahrarnoho i silskoho rozvytku v suchasnii ahrarnii politytsi [Fundamentals of Harmonization of Agrarian and Rural Development in Modern Agrarian Policy]. Ekonomika Ukrainy - Ukraine economy, 10, 32-43 [in Ukrainian].

11. Kaletnik, H.M. (2013). Rozvytok rynku biopalyv v Ukraini [Development of the Biofuels Market in Ukraine]. Bioenerhetyka - Bioenergy, 1, 11-16 [in Ukrainian].

12. Kovalova, O.V. Shchodo napriamiv rozvytku orhanichnoho vyrobnytstva silskohospodarskoi produktsii $\mathrm{v}$ Ukraini: analit. zap. [Regarding the directions of development of organic production of agricultural products in Ukraine: analyt. note]. Natsionalnyi instytut stratehichnykh doslidzhen: veb-sait - National Institute for Strategic Studies: Web site. Retrieved from http://www.niss.gov.ua/articles/1292/ [in Ukrainian].

13. Drabovskyi, A.H. (2018). Problemy ta perspektyvy rozvytku okremykh kooperatyvnykh form hospodariuvannia $\mathrm{v}$ ukrainskii ekonomitsi [Problems and prospects of development of separate cooperative forms of management in the Ukrainian economy]. Visnyk Volynskoho instytutu ekonomiky ta menedzhmentu - Bulletin of the Volyn Institute of Economics and Management. 21, 64-73 [in Ukrainian].

14. Burdyha, I. (2018). Nove pokolinnia na zviazku: koly v Ukraini zapratsiuie 4G [A new generation of communications: when 4G will work in Ukraine]. Hromadske telebachennia: veb-sait - Public Television: Web site. Retrieved from https://hromadske.ua/posts/koli-v-ukraini-zapracyue-4g [in Ukrainian].

\section{Інформація про автора}

КОЛЕСНИК Тетяна Василівна - кандидат економічних наук, доцент кафедри адміністративного менеджменту та альтернативних джерел енергії, Вінницький національний аграрний університет (21008, м. Вінниця, вул. Сонячна, 3, e-mail: sergej.kolesnik@gmail.com).

KOLESNIK Tetyana - Candidate of Economic Sciences, Associate Professor of the Department of Administrative Management and Alternative Energy, Vinnytsia National Agrarian University (21008, Vinnytsya, 3 Soniachna Str., e-mail: sergej.kolesnik@gmail.com).

КОЛЕСНИК Татьяна Васильевна - кандидат экономических наук, доцент кафедры административного менеджмента и альтернативных источников энергии, Винницкий национальный аграрный университет (21008, г. Винница, ул. Солнечная, 3, e-mail: sergej.kolesnik@gmail.com). 